\title{
Kurumsal Bilgi Sistemleri İçerisinde Belge Yönetimi: Türkiye'deki Kamu Üniversitelerinde Gerçekleştirilen Uygulamalara Yönelik Bir Durum Analizi
}

\author{
Records Management in Enterprise Information \\ Systems: A Case Study Carried Out on the Practices in \\ States Universities of Turkey
}

\author{
Özgür KÜLCÜ", Tolga ÇAKMAK"ve Nevzat ÖZEL***
}

\begin{abstract}
Öz
Bilgi toplumuna geçişle birlikte yönetim anlayışlarındaki değişiklikler, teknolojik olanaklar doğrultusunda geliştirilen standartlar, analiz araçları, düzenlemeler ve yasal uygulamalar kurumsal içeriğin yönetimine yeni boyutlar kazandırmaktadır. Günlük iş süreçlerini, iç işleyişleri ve çevre ile olan etkileşimler doğrultusunda yürüten kurumlar, sahip oldukları farklı bilgi kaynaklarına yönelik işlevler taşıyan sistemler geliştirmek, bu sistemlerden faydalanmak, bilgi sistemleri ile ilgili tüm gelişmeleri takip etmek durumundadırlar. Kurumsal işleyişlerini bilgi sistemleri ile yürüten üniversiteler sahip oldukları kurumsal yapılarla ön plana çıkmaktadırlar. Bu araştırma ile Türkiye'de üniversitelerdeki kurumsal bilgi ve belge sistemlerineyönelik uygulamalara ilişkin benzer ya da farklı yönlerin neler olduğu, uyum ve eşgüdüm sorunu yaşanıp yaşanmadığı, 22 üniversitede gerçekleştirilen yarı yapılandırılmış görüşmeler ve geliştirilen bir durum listesi aracılığıyla belirlenmeye çalışılmıştır. Araştırma kapsamında elde edilen bulgular, üniversitelerin kurumsal bilgi sistemlerinin yönetimine dönük uygulamalarında eksikliklerinin bulunduğunu, belge yönetim sistemleri ile ilgili süreçlerde iyileştirmelere ihtiyaç olduğunu ortaya çıkarmıştır.
\end{abstract}

Anahtar sözcükler: Bilgi sistemleri, Belge yönetimi, Üniversiteler, Türkiye

\begin{abstract}
Changes in managerial approaches with the transition to information society, developed standards, assessment tools, legislations and regulations bring new dimensions to management of organizational information. Organizations managing daily workflows according to internal and external interactions, should use, develop and implement information systems that have different functions for different information assets. Furthermore, organizations should also follow updates related to information system. In this regard, universities with their organizational structures come into prominence among the organizations that are carrying their work processes
\end{abstract}

* Doç. Dr. Hacettepe Üniversitesi, Bilgi ve Belge Yönetimi Bölümü. (kulcu@hacettepe.edu.tr)

* Arş. Gör. Hacettepe Üniversitesi, Bilgi ve Belge Yönetimi Bölümü. (tcakmak@hacettepe.edu.tr)

*** Arş. Gör. Ankara Üniversitesi, Bilgi ve Belge Yönetimi Bölümü. (nozel@ankara.edu.tr) 
out with information systems. In this context, this study has revealed the similarities and differences of the practices, and exposed the consistency and interoperability problems in current situations of organizational information and records systems at 22 universities in Turkey via a semi-structured interview and a developed checklist. Findings indicate that there are deficiencies in the managerial applications of organizational information and records systems of universities and they need revisions and improvements in some important points with regard to the processes.

Keywords: Information systems, Records management, Universities, Turkey

\section{Giriş}

Kurumların giderek artan rekabet ortamında mücadele edebilmeleri için iç ve dış kullanıcıların gereksinimlerinin karşılanabilmesinde ve hizmetlerini geliştirmelerinde bilgi yönetimi uygulamaları son derece önemlidir. Söz konusu uygulamaları gerçekleştirebilmek ve etkinlikle yönetebilmek için kurumlar, altyapı olanaklarını sürekli olarak geliştirmekte ve bu noktada bilgi sistemlerinden faydalanmaktadırlar. Güçlü bilgi sistemlerine sahip olan kurumlar, kendi sektörlerinde kurumsal etkililiği sağlamaya yönelik olarak başta maliyet ve zaman yönetimi gibi konular olmak üzere birçok noktada önemli avantajlar elde etmektedirler. Bu bağlamda kurumlar, iş süreçlerinde bilgi akışının sağlanması için farklı işlevlere sahip birçok sistemden ve araçtan faydalanmaktadırlar. Bilgi sistemleri, idari yapılarına ve kültürlerine göre fonksiyonlar tanımlamakla birlikte kurumsal kararlara da kaynak teşkil etmektedir. Diğer yandan teknolojik olanaklar ve yaşanan gelişmeler, kurumlarda farklı içerikte bilgi kaynaklarının hızla çoğalmasına yol açmakta; bu kaynakları toplama, düzenleme ve kullanıma sunma gibi hayati işlevlere sahip bilgi sistemlerinin de sürekli olarak geliştirilmesini ve yeni teknolojilerle uyumlu hale getirilmesini gerektirmektedir. Bu çerçevede hangi sektörde olursa olsun kurumlar, sahip oldukları bilgi sistemlerini kullanım, güvenlik ve riskler gibi çeşitli açılardan analiz ederek geliştirdikleri görülmektedir. Konuyla ilgili literatür incelendiğinde risk analizleri ve bilgi güvenliği boyutları da dahil olmak üzere birçok değerlendirme aracının oluşturulduğu dikkati çekmektedir. Değerlendirme araçlarından elde edilen sonuçların da bilgi sistemlerinin farklı boyutlara gelmesinde etkili olduğunu söylemek mümkündür. Yapılan çalışmalarda da kurumsal bilgi sistemlerinin boyutlarının ofis ortamlarında verimliliği sağlamadan, bütünsel olarak kurumsal verimliliği artırmaya yönelik uygulamalara doğru genişlediği vurgulanmıştır (Cimtech Ltd., 2009).

Üniversiteler, idari ve akademik teşkilatlarının kapsamı ve büyüklüğü ile diğer eğitim kurumlarından ayrılırlar. Bu teşkilat yapısı içerisinde üniversiteler kurumsal iletişim ve iş süreçlerini; web içerik yönetimi sistemleri, doküman yönetim sistemleri, e-posta sistemleri ve belge yönetim sistemleri gibi farklı bilgi sistemleri ile gerçekleştirirler. Türkiye'de kamu üniversiteleri aynı idari ve yasal çerçevede hizmetlerini yürütmelerine karşın, kurumsal iletişim ve bilgi sistemlerini birbirlerinden bağımsız şekilde yapılandırmaktadırlar. Bu durum benzer iş süreçlerine yönelik farklı ve zaman zaman eşgüdüm sorununa yol açabilecek uygulamalara neden olabilmektedir. 
Bu bilgiler doğrultusunda çalışmada kurumlarda bilgi sistemleri ve bilgi sistemlerine yönelik uygulamalar kuramsal çerçevede ele alınırken, Türkiye'de üniversitelerde kullanılan bilgi sistemleri ile ilgili uygulamaların ve mevcut durumun değerlendirilmesi için 22 üniversitede yapılan bir araştırmaya yer verilmektedir. Bunun yanı sıra çalışmada gerçekleştirilen araştırmanın sonuçları ve bu bağlamda Türkiye'de üniversitelerde kullanılan bilgi sistemlerine yönelik iyileştirmelerle ilgili öneriler sunulmaktadır.

\section{Kurumsal Bilgi Sistemlerinin İşlevleri ve Kullanımı}

Kurumsal fonksiyonların daha etkin yürütülebilmesi için bilgi teknolojisinin sunduğu imkânların aktif olarak kullanılması gerekmektedir. Bilgi teknolojileri çerçevesinde geliştirilen kurumsal çözümler, bilgi sistemleri, sunucular, iletişim ortamları gibi donanım ve yazılımları içeren altyapı bileşenleri kurumsal bilginin yönetiminde temel yapı taşı olarak nitelendirilmektedir (Barutçugil, 2002, s.125; Spiegler, 2002, s.2). Söz konusu bileşenler içerisinde yer alan kurumsal bilgi sistemleri, kurum içinde üretilen veya kuruma dışarıdan gelen, o kurumla ilgili kayıtlı ya da kayıtsız her türlü bilgiyi kapsayan sistemler olarak ifade edilmekte; kurumsal iş süreçlerinin elektronik ortam üzerinden yönetiminde hayati değere sahip bir bileşen olarak gösterilmektedir (Odabaş, 2003, s.359). Kurumsal bilginin stratejik açıdan sermaye kadar önemli bir güce dönüşmesi ve bilginin kurumsal üretim faaliyetleri etkin biçimde yer alması, kurumsal bilgi sistemlerinin kurumlar için hayati değer taşıyacak bir konuma gelmesine yol açmıştır (Çeven, 2006, s.5; Özdemirci ve Aydın, 2007, s.165).

Kurumsal yapılar genel olarak düşünüldüğünde, kurumların farklı iş süreçlerine hitap eden (web içeriği, e-posta yönetimi, belge yönetimi gibi) bilgi sistemlerinden faydalanarak fonksiyonlarını yürüttükleri söylenebilir. Farklı araçlar kullanılmasına rağmen bilgi sistemleri, kurumsal yapı, kültür ve kimlik doğrultusunda geliştirilmekte ve özelleştirilmekte; kurumsal kaynak planlama ve içerik yönetimi yazılımları aracılığıyla bütünleşik bir platform üzerinden de kullanılabilmektedir (Çakmak, 2011).

Kurumsal bilgi sistemleri yapılandırılırken, gelişen teknolojik olanaklar, kurumun örgütsel yapısındaki farklılaşmalar, kurum kültürü ve hizmet verilen kullanıcı grubundaki değişimler göz önüne alınmalıdır. Kurumsal bilginin yönetimi konusunda çalışan uzmanlar, bütün bu değişim ve gelişmeleri göz önünde bulundurarak bilginin yönetimi konusunda bir takım fonksiyonlar açıklamışlardır. Bu fonksiyonları aşağıdaki başlıklarda özetlemek mümkündür (Laudon ve Laudon, 2000, s.7; Şahin, 2005, s.5; Kumar ve Mittal, 2004, s.1; Demir, 2000, s.16; Çeven, 2006, s.16);

$\diamond$ Bilgiyi kurumsal süreçlerde denetim altına alma,

$\diamond \quad$ Karar vermeyi destekleyecek şekilde bilgiyi toplama, işleme, saklama, ilgili kurumsal bölümlere dağıtma,

$\diamond \quad$ Veri kaynaklarını girdi olarak kullanarak işleme ve sonuçta veri kaynaklarını bilgiye dönüştürerek dağıtma, 
$\diamond$ Kurumsal işleyişte veri kaynakları, insanlar, donanım, yazılım ve iletişim ağı arasındaki bağlantıyı sağlama,

$\diamond$ Kurumsal hedefler doğrultusunda süreçleri ön planda tutarak alt sistemlerde/ modüllerde bulunan bilgileri bütünsel bir platformda toplayarak kullanıcıların bilgi ve veri ihtiyacını karşılama,

$\diamond$ Kurumsal süreçlerde dağıtık bir yapıda bulunan bilgiler bütünsel bir platform üzerinden sunma.

Belirtilen işlevlere dayanarak kurumsal bilgi sistemlerinin kurumların iç ve dış bilgi kaynaklarının etkin kullanımında önemli bir araç olduğu, aynı zamanda alt sistemlerden/ modüllerden oluştuğu ve bütünsel bir yaklaşımın benimsendiği bir yazılım stratejisini içerdiği söylenebilir. Kurumsal bilgi sistemlerine yönelik olarak gerçekleştirilen bilimsel çalışmalar değerlendirildiğinde, yapılan tanımlamaların amaç ve işlevleri vurgulamanın yanı sıra bütünleşik bir sistem mimarisini ve merkezi bir yönetim sistemini yansıtmaya yönelik ifadeleri içerdiği de dikkati çekmektedir. Bu tür çalışmalar Mabert, Soni ve Venkataraman (2001), Bingi, Golda ve Sharda (1999), Parr ve Shanks (2000) tarafından aynı zamanda "kurumsal kaynak planlaması" olarak da ifade edilmektedir.

\section{Kurumsal Bilgi Sistemleri Olarak Belge Yönetim Sistemleri ve Uygulamaları}

Kurumlarda belgeler resmi iletişimi ve kurum içi bilgi alış verişini sağlayan, geriye dönük uygulamalara ışık tutan, idari - yasal denetim ve doğrulama uygulamaları için kanıt niteliği taşıyan, yönetimin kararları için gerekli bilgiyi bulunduran, içeriği ve form yapıları önceden belirlenmiş dokümanter kaynaklardır. Bu kaynakların etkin yönetimi kurumsal uygulamalarda başarı için gereklidir (Cisco ve Strong, 1999, s.172; Dollar, 2002, s.22; Penn, Mordel ve Pennix 1994, s.5; Shepherd ve Geoffrey, 2003, s.13). Kurumların idari sistemleri içerisinde tanımlanan belge yönetimi uygulamalarında başarı için, kurum içerisinde idari yapı ve belge uygulamalarına yönelik var olan kapasitenin analiz edilmesi oldukça önemli görülmektedir. Kurumlarda belge yönetimi uygulamaları için bir durum saptaması yapmak üzere gerçekleştirilecek analizlerde, analiz ölçütlerini doğru belirlemek gerekmektedir. Bu kapsamda belge işlemlerini etkileme kapasitesine sahip, kurumsal ve ulusal koşullar ile uluslararası düzenlemeler ve standartlar göz önünde bulundurulmak durumundadır (Information Management Planning, 2005; Shepherd ve Geoffrey, 2003, s.xii-xiii; Williams, 2002, s.6).

Kurumlarda belge yönetimi uygulamaları geliştirilirken kurumun bağlı olduğu tüm birim ve bölümlerde belge işlemlerinin, sorunların ve beklentilerin tanımlanması gerekli görülmektedir. Diğer yandan bağlı olunan yasal çevre ve ilgili alanda geliştirilen yol gösterici nitelikteki düzenlemeler de belge yönetimi uygulamalarına yönelik olarak program geliştirme aşamalarında etkin olarak kullanılmaktadır (Pember, 2006, s.22; Shepherd ve Geoffrey, 2003, s.30-31; Spratt, 2004, s.8; Zawiyah ve Chell, 2002, s.55). 
Ancak Türkiye'de kurumların önemli bir bölümü, kendi gereksinimleri doğrultusunda bir belge yönetim programı geliştirememiştir. Bu durum, kurumlar için özel beklentilerin karşılanmasını olanaksız hale getirmekte, beraberinde bürokratik yavaşlama, belgelere erişilmeme gibi sorunlara da yol açabilmektedir. Bu sorunların aşılmasında, kurumun yapı ve işleyişini tanımlamaya dönük analizlerin yapılması, belge yönetimi alanında uluslararası koşulların değerlendirilmesi önemli olarak kabul edilmektedir (Demp, 2004, s.11; Griffin, 2004, s.74; Thurston, 2005, s.4).

İçsel ve dışsal unsurlarla iletişim halinde olan tüm kurumlar, önceden belirlenmiş bir sistem içerisinde belge üretir, sağlar, belirli bir süre saklar, gereksiz olanları imha eder ya da belgelerin uzun süreli kullanım değeri söz konusuysa arşive kaldırırlar. Kurumlar büyüdükçe mevcut belge sistemine duyulan gereksinim artmakta ve daha sistematik düzenlemelere gereksinim duyulmaktadır. Ortamı ne olursa olsun yürütülen bir işin nerede, ne zaman, kim tarafından ve ne şekilde gerçekleştirildiğini ortaya koyan, içsel ve dışsal iletişimi sağlayan, özgün ve güvenilir bilgi kaynakları olarak kabul edilen belgelere ve belge yönetim uygulamalarına dönük sistemlere gereksinim söz konusudur (Hare ve McLeod, 1997, s.3; Penn, Mordel ve Pennix, 1994, s.5; Smith ve Kallaus, 1997, s.4). Illetişim ve bilgi teknolojilerinin hızla değişimiyle bu sistemlere duyulan gereksinim artmaktadır. Küreselleşme süreci ise, bir yandan var olan belge sistemlerini tehdit eden; ancak öte yandan uluslararası düzenlemeler ve uygulamalar çerçevesinde yeniden yapılanma çalışmalarını destekleyen bir etkiye sahip olmuştur. Bu çerçevede, geliştirilen ve uluslararası standartlar, rehberler, uygulama örnekleri küresel kalkınmanın vazgeçilmez unsuru olarak görülmektedir. Belge yönetimi alanında geliştirilen ve uluslararası geçerliliğe sahip düzenlemeler, alandaki uygulamaları kurumsal ve ulusal sınırların ötesine taşıyarak, belge yönetiminin uluslararası bir disiplin olarak gelişimine önemli katkılar sağlamaktadırlar (Duff ve McKemmish , 2000, s.4; Cain, 2002, s.15; Külcü ve Uzun Külcü, 2009; Spratt, 2004, s.8).

Türkiye'de belge yönetiminde ve arşivcilik uygulamalarında izlenecek yöntemleri ortaya koyan çalışmalar ve yasal düzenlemeler konuya ilişsin kurumsal uygulamalara yön vermektedir (Ayıklama ve İmha Komisyonlarına ait Çalışma Rehberi, 1996; Devlet Arşiv Hizmetleri Hakkında Yönetmelik, 1988; Devlet Arşiv Hizmetleri Hakkında Yönetmelikte Değişiklik Yapılmasına Dair Yönetmelik, 2001; Muhafazasına Lüzum Kalmayan Evrak ve Malzemenin Yok Edilmesi Hakkında Kanun, 1988; Resmi Yazışmalarda Uygulanacak Esas ve Usuller Hakkında Yönetmelik 2004). Ayrıca, Bilgi Edinme Hakkı Kanununun kurumlarda belge yönetimi uygulamalarının yapılandırımasını, Elektronik İmza Kanununun elektronik ortamda yasal geçerliliği olan belge işlemlerinin yürütülebilmesini, Standart Dosya Planının kamu kurumlarında belgelerin standart biçimde tanımlanmasını sağlamıştır (Bilgi Edinme Hakkı Kanunu, 2003; Elektronik İmza Kanunu, 2004; Standart Dosya Planı, 2005). Yine belge yönetimi alanında uluslararası standart olan ISO 15489'un TSE tarafından da bir Türk standardı olarak kabulü ve elektronik belge yönetimi yazılım uygulamalarına referans model olan TS 13298'un yayımlanması alanın gelişimine önemli katkı sağlamıştır (TS 13298, 2009; TS ISO 15489-1-2). 
Bu çerçevede, örnek bir proje Ankara Üniversitesi Belge Yönetimi ve Arşiv Sistemi Projesi (BEYAS)'dir. 2007 yılında çalışmalarına başlanan bu proje ile Üniversitedeki belge ve arşiv işlemlerinin, belge yönetimi ve arşivcilik ilke ve yöntemlerine göre yürütülebilmesini sağlamak ve Türkiye'deki tüm üniversitelere kılavuz olacak bir "Belge Yönetimi ve Arşiv Sistemi Modeli" oluşturmak hedeflenmiştir (Özdemirci, 2009).

Türkiye'de belge yönetimi alanında çalışmalar 1990'lı yılların ortalarından itibaren artış göstermiştir. Özdemirci $(1996,2012)$, İcimsoy $(1997)$ ve Kandur $(1998,2011)$ tarafından gerçekleştirilen çalışmalar, alanın gelişimine önemli katkılar sağlamıştır. 2000'li yıllarla birlikte Çiçek (2000), Külcü (2005) ve Odabaş (2007) belge yönetimini farklı unsurları da içine alacak biçimde incelemiştir. Türkiye'de uluslararası belge yönetimi standardı ISO 15489'un farklı açılardan değerlendirildiği çalışmaların (Özdemirci, 2004) yanı sıra belge yönetiminde standartlaşma ve uluslararası uygulamaları ele alan çalışmaların da yayımlandığı gözlemlenmiştir (Külcü, 2006).

\section{Yöntem}

Araştırmamız, kurumsal bilgi sistemleri ve belge yönetimi uygulamaları üniversitelerde gerçekleştirilen süreçler çerçevesinde değerlendirilmiştir. Bu çerçevede sosyal bilimler alanında yaygınlıkla kullanılan araştırma yöntemi olan betimleme yönteminden faydalanarak araştırma deseni geliştirilmiş; nitel ve nicel veriler elde edilmiştir.

\section{Araştırma Modeli ve Araştırma Soruları}

Üniversitelerde gerçekleştirilen bilgi ve belge sistemlerine yönelik uygulamaların analiz edilmesi için literatürde durum ve uygulamaları olduğu şekliyle betimlemeyi amaçlayan araştırma yaklaşımı olarak tanımlanan tarama modelleri kullanılmıştır (Karasar, 2004, s.77). Ayrıca üniversitelerdeki uygulamaları derinlemesine inceleyebilmek için tarama modelleri kapsamında yer alan örnekolay tarama modelinden faydalanılmıştır.

Kullanılan araştırma modeli doğrultusunda üniversitelerde bilgi sistemleri ve belge yönetimi uygulamalarına yönelik olarak aşağıdaki araştırma sorularına yanıt aranmıştır:

1. Üniversitelerde arşiv ve belge yönetimi uygulamalarına yönelik koşullar ve yapılanma nasıldır?

2. Üniversitelerde web içerik, e-posta ve belge yönetimi gibi iş süreçlerinde kullanılan kurumsal bilgi sistemlerine yönelik koşullar nasıldır?

3. Üniversitelerde iş süreçlerinde kullanılan kurumsal bilgi sistemlerinin yönetimi ve güvenliği ile ilgili karşılaşılan sorunlar nelerdir? 


\section{Örneklem, Veri Toplama Teknikleri ve Veri Analizi}

Gerçekleştirilen analizlere ilişkin örneklem seçiminde kasıtlı örnekleme tekniği kullanılmıştır. Bu teknik doğrultusunda analizler, Türkiye'de idari ve akademik personel sayısına göre sıralamada ilk 35'e giren kamu üniversiteleri arasından izin alınabilen 22 üniversiteye yönelik olarak gerçekleştirilmiştir (Tablo I), 124 sayılı KHK çerçevesinde bilgi ve belge işlemlerinin yürütülmesinden sorumlu genel sekreterlik makamları, genel evrak ve arşiv birimleri ile bilgi işlem dairesi başkanlıkları araştırma kapsamında analiz edilen birimler olmuştur.

Tablo I. Saha Çalışmalarının Yürütüldüğü Üniversitelerin İdari ve Akademik Personel Sayıları

\begin{tabular}{lcc}
\hline Üniversite Adı & İdari Personel & Akademik Personel \\
\hline Adnan Menderes Üniversitesi & 484 & 412 \\
Akdeniz Üniversitesi & 600 & 583 \\
Anadolu Üniversitesi & 675 & 659 \\
Ankara Üniversitesi & 1652 & 1621 \\
Boğaziçi Üniversitesi & 391 & 363 \\
Celal Bayar Üniversitesi & 467 & 387 \\
Çukurova Üniversitesi & 760 & 764 \\
Dokuz Eylül Üniversitesi & 1092 & 1129 \\
Ege Üniversitesi & 1125 & 1380 \\
Fırat Üniversitesi & 617 & 629 \\
Hacettepe Üniversitesi & 1308 & 1354 \\
İstanbul Teknik Üniversitesi & 671 & 854 \\
Karadeniz Teknik Üniversitesi & 639 & 596 \\
Kocaeli Üniversitesi & 532 & 428 \\
Mersin Üniversitesi & 532 & 417 \\
On Dokuz Mayıs Üniversitesi & 589 & 718 \\
Sakarya Üniversitesi & 637 & 475 \\
Selçuk Üniversitesi & 751 & 897 \\
Trakya Üniversitesi & 446 & 401 \\
Uludağ Üniversitesi & 719 & 730 \\
Yıldız Teknik Üniversitesi & 458 & 536 \\
\hline
\end{tabular}

Veriler Yükseköğretim Kurumu Web sayfası (saha çalışmalarının başladığı Nisan 2011 itibariyle) ile ilgili üniversitelerin faaliyet raporları yanında Sakarya Üniversitesi ve Anadolu Üniversitesi verileri personel dairesi başkanlığı ile yapılan telefon görüşmeleri ile elde edilmiştir.

Araştırma kapsamında veri toplama tekniği olarak "sözlü iletişim yoluyla veri toplama tekniği" (Karasar, 1991, s.165) olarak tanımlanan görüşme tekniği kullanılmıştır. Bu doğrultuda, araştırmada verilerin elde edilmesi için görüşme tekniğinin bir türü olan ya- 
pılandırılmış görüşmeden yararlanılmıştır. Görüşmeler, kurum içerisinde bilgi teknolojilerine yönelik uygulamalarının yürütülmesinden sorumlu Bilgi İşlem Dairesi Başkanı ve bağlı yöneticiler ile konu uzmanı personelle gerçekleştirilmiştir. Araştırmada ayrıca derinlemesine sonuçlar elde edebilmek için “Üniversitelerde Bilgi Teknolojilerine Yönelik Koşullar: Analiz Formu" başlığını taşıyan bir durum listesi de geliştirilmiştir. Biri açık uçlu, dördü çoktan seçmeli ve onu evet/hayır şeklindeki sorulardan oluşan bu analiz aracı öncelikle pilot çalışma olarak 8 üniversitede uygulanmış, ilgili çalışmayı değerlendiren TÜBITAK yetkililerinin önerileri çerçevesinde güncellenmiştir. Güncellemeleri yapılan bu araç, Tablo I'de verilen ve izin alınan üniversitelerin tamamında uygulanmıştır.

Geliştirilen veri toplama aracı ve kullanılan veri toplama teknikleri ile elde edilen verilerin analizinde verilerin sıklık ve yüzde değerlerine göre yorumlanmasını ifade eden tanımlayıcı istatistiklerden (Baş, 2001, s.128) yararlanılmıştır. Tanımlayıcı istatistiklerin elde edilmesinde ise PASW (Predictive Analytics SoftWare) yazılımı kullanılmıştır.

\section{Bulgular}

Araştırmanın gerçekleştirildiği 22 üniversite, kamu üniversitesi niteliğindedir. Kamu üniversitelerinin idari ve akademik yapıları, 2547 Sayılı Yükseköğretim Kurulu Kanunu ile 124 sayılı Yükseköğretim Üst Kuruluşları ile Yükseköğretim Kurumlarının İdari Teşkilatı Hakkında Kanun Hükmünde Kararname'ye (KHK) dayalı olarak yapılandırılmaktadır. 124 sayılı KHK'nin 5.maddesinde üniversitelerin idari teşkilatında genel sekreterlik makamı "Yükseköğretim Kurulu İdari Teşkilatının başı" olarak tanımlanmaktadır (124 Sayılı Kanun Hükmünde Kararname, 1983; Yükseköğretim Kanunu, 1981). Üniversitelerde Genel Sekreterlik Makamı idari sistemin parçası olarak aynı zamanda kurumsal belge ve arşiv hizmetlerinden sorumlu en üst makamdır.

Bu çerçevede, Yükseköğretim Kurulunun 25 Şubat 2010 tarih ve 037/1420 sayılı izinlerine dayanarak 22 Üniversitenin Genel Sekreterlik Makamı ile doğrudan iletişime geçilerek gerçekleştirilmiş; öncelikle araştırmaya katılan üniversitelerin belge ve arşiv işlemlerinden sorumlu birimlerinin hangi birimler olduğu incelenmiştir (Tablo II).

Tablo II. Üniversitelerde Belge ve Arşiv İşlemlerinden Sorumlu Merkezi Birim

\begin{tabular}{lcc}
\hline Birim Adı & $\mathbf{n}$ & \% \\
\hline Genel Sekreterlik Makamı & 7 & 31,8 \\
Arşiv Birimi & 6 & 27,4 \\
Her birimin bağımsız & 7 & 31,8 \\
Kütüphane ve Dokümantasyon Daire Başkanlığı & 1 & 4,5 \\
İdari ve Mali İ̧ler Dairesine Bağıı Kurum Arşivi & 1 & 4,5 \\
\hline Toplam & $\mathbf{2 2}$ & $\mathbf{1 0 0 , 0}$ \\
\hline
\end{tabular}


Tablo II'deki bulgulara göre, üniversitelerin \%31,8'inde kurum içi ve kurum dışı, diğer kişi ve organizasyonlar arasındaki yazışmaların ve diğer resmi bilgi ve belge işlemlerine dönük süreçlerin Genel Sekreterlik Makamı tarafından gerçekleştirildiği anlaşılmaktadır. Üniversitelerin \%27,3'ünün arşiv hizmetlerinden sorumlu merkezi bir birime sahip oldukları görülmektedir. Diğer taraftan bu üniversitelerin \%31,8'inin ilgili çalışmalara ilişkin merkezi bir yapılanmaya sahip olmaması ve bu çalışmaların yürütülmesinin ve koordinasyonunun doğrudan birimlere bırakılması dikkat çekicidir. Sadece bir üniversite Kütüphane ve Dokümantasyon Daire Başkanlığını, bir üniversite de İdari ve Mali İşler Dairesine Bağlı Kurum Arşivini belge ve arşiv hizmetlerinden sorumlu birim olarak göstermiştir. Sonuçlar kamu üniversitelerinin kurumsal iletişim, bilgi ve belge işlemlerinin yürütülmesinden ve koordinasyonundan sorumlu merkezi bir birim teşkilatlanması konusunda dağınık bir yapıya sahip olduklarını göstermektedir. Araştırmada üniversitelerdeki belge ve arşiv uygulamalarına yönelik koşullara ilişkin bulgular ise Tablo III'de sunulmuştur.

Tablo III. Üniversitelerde Belge ve Arşiv Uygulamalarına Yönelik Koşullar

\begin{tabular}{|c|c|c|c|c|c|c|}
\hline \multirow{2}{*}{ Uygulamalar } & \multicolumn{2}{|c|}{ Evet } & \multicolumn{2}{|c|}{ Hayır } & \multicolumn{2}{|c|}{ Toplam } \\
\hline & $n$ & $\%$ & $\mathbf{n}$ & $\%$ & $\mathbf{n}$ & $\%$ \\
\hline Belge işlemlerini tanımlamaya yönelik bir yönerge var mı? & 10 & 45,5 & 12 & 54,5 & 22 & 100 \\
\hline Üniversite içi yazışmalar elektronik ortamda mı yürütülüyor? & 4 & 18,2 & 18 & 81,8 & 22 & 100 \\
\hline Diğer kurumlarla yazışmalar elektronik ortamda mı yürütülüyor? & 1 & 4,5 & 21 & 95,5 & 22 & 100 \\
\hline $\begin{array}{l}\text { Üniversite, Standart Dosya Planı (SDP) uygulamasına geçiş } \\
\text { yaptı mı? }\end{array}$ & 17 & 77,3 & 5 & 22,7 & 22 & 100 \\
\hline $\begin{array}{l}\text { Üniversitede üretilen ya da kullanılan belgelere yönelik saklama } \\
\text { planları geliştirilmiş mi? }\end{array}$ & 13 & 59,1 & 9 & 40,9 & 22 & 100 \\
\hline $\begin{array}{l}\text { Güncelliğini kaybeden belgelerin tasfiyesi için ayıklama ve imha } \\
\text { komisyonları oluşturuluyor mu? }\end{array}$ & 18 & 81,8 & 4 & 18,2 & 22 & 100 \\
\hline $\begin{array}{l}\text { Birim ve dairelere ait arşivler dışında üniversitenin merkezi bir } \\
\text { arşivi var mı? }\end{array}$ & 11 & 50,5 & 10 & 49,5 & 21 & 100 \\
\hline
\end{tabular}

Üniversitelerdeki belge ve arşiv uygulamalarına yönelik koşullar değerlendirildiğinde, araştırma kapsamındaki üniversitelerin yarısından fazlasının $(\% 54,5)$ belge ve arşiv hizmetlerine yönelik yönergesinin bulunmadığı görülmektedir. Oysa Devlet Arşiv Hizmetleri Hakkında Yönetmelik/Mükelleflerce Hazırlanacak Arşiv Yönergesi'nin 45. maddesi hükmünce kurum veya kuruluşların hususiyeti ve ürettiği evrakın özelliğinden kaynaklanan durumlarda, aykırı olmamak kaydı ile Devlet Arşivleri Genel Müdürlüğü'nün uygun görüşü alınarak, 3 ay içerisinde kendi arşiv yönergelerini hazırlamaları gerekmektedir. Yasal olarak arşiv yönergesi oluşturma zorunluluğunun bulunmasına rağmen, üniversitelerin yarısından fazlasının arşiv yönetmeliğine sahip olmaması eleştirilebilir. Araştırmada sorulan soruların üniversitelerin Genel Sekreterlik Makamınca görevlendirilen, üniversite içerisinde konulardan sorumlu kişilerce 
yanıtlandığı düşünüldüğünde, varsa konuya ilişkin bilgi eksikliği, daha da ciddi bir sorunu ortaya koymaktadır. Üniversitelerin yalnızca \%18,2'si yazışmalarını bütünüyle elektronik ortama geçirmiştir. Gerçekleştirilen görüşmelerde üniversitelerin önemli bir kısmı ise konuya ilişkin çalışmalarını sürdürmektedir. Bazı üniversiteler de belirli idari birim ve fakültelerde uygulamaya geçmesine rağmen elektronik belge sistemleri üniversitenin tamamında uygulamamaktadır. Diğer kurumlarla yapılan yazışmaları elektronik ortamda gerçekleştirdiğini belirten sadece bir üniversite bulunmaktadır. Üniversitelerin 2002 yılında yayımlanan ve tüm kamu kurumlarında uygulanmasına dönük genelge bulunan Standart Dosya Planı Uygulamasına (Standart Dosya Planı İle İlgili Başbakanlık Genelgesi, Başbakanlık Genelgesi, Sayı: 320-8880, 11 Haziran 2002) henüz beş üniversite geçiş yapamamıştır. Üniversitelerin \%40'ından fazlası üniversitede üretilen ya da kullanılan belgelere yönelik saklama planına sahip değildir. Bu durum arşiv depolarında ayıklama yapılamadığı için gereksiz yığılmalara yol açacağı gibi, günlük kullanımda gerekli olan belgelere erişime dönük de ciddi sıkıntılara yol açabilecektir.

Üniversitelerin \%80'inden fazlasının güncelliğini kaybeden belgelerin tasfiyesi için ayıklama ve imha komisyonlarını oluşturduğunu dile getirmesine karşın, bu uygulamaları saklama planları olmadan nasıl gerçekleştirdiği tartışma konusudur. Üniversitelerin neredeyse yarısının $(\% 49,5)$ birim ve dairelere ait arşivler dışında kurum arşivine sahip olmadıkları görülmektedir. Bu durum Devlet Arşiv Hizmetleri Hakkında Yönetmelik çerçevesinde birimlerden ayıklanması ve merkezi arşivlerde saklanması gereken belgelerin birimlerde korunmaya çalışmasına, dolayısıyla yığılmalara ve koordinasyon eksikliğinden kaynaklanan bir dizi sorunun yaşanmasına neden olabileceği göz önünde bulundurulmalıdır. Üniversitelerin basılı ve elektronik belge/ arşiv kaynaklarının korunması ve güvenliği ile ilgili koşullarına yönelik bulgular ise Tablo IV'de verilmiştir.

Tablo IV. Basılı ve Elektronik Belge/Arşiv Kaynaklarının Korunması ve Güvenliği ile İlgili Koşulları

\begin{tabular}{|c|c|c|c|c|c|c|}
\hline \multirow{2}{*}{ Uygulamalar } & \multicolumn{2}{|c|}{ Evet } & \multicolumn{2}{|c|}{ Hayır } & \multicolumn{2}{|c|}{ Toplam } \\
\hline & $\mathbf{n}$ & $\%$ & $\mathbf{n}$ & $\%$ & $\mathbf{n}$ & $\%$ \\
\hline $\begin{array}{l}\text { Belgelere erişim ve yetkilendirmelerin tanımlandığı } \\
\text { düzenlemeler mevcut mu? }\end{array}$ & 6 & 27,3 & 16 & 72,7 & 22 & 100 \\
\hline $\begin{array}{l}\text { Gizli ve önemli belgeler farklı alanlarda özel mekanizmalı raflarda } \\
\text { korunuyor mu? }\end{array}$ & 12 & 54,5 & 10 & 45,5 & 22 & 100 \\
\hline Elektronik imza sertifikalı yazışmalar yürütülüyor mu? & 2 & 9,1 & 20 & 90,9 & 22 & 100 \\
\hline $\begin{array}{l}\text { Bilgi güvenliğine dönük ISO 27001, ISO } 23081 \text { gibi standartlar } \\
\text { uygulanıyor mu? }\end{array}$ & 2 & 9,1 & 20 & 90,9 & 22 & 100 \\
\hline $\begin{array}{l}\text { Elektronik belge ve arşiv kaynaklarına yönelik bir dijital arşiv } \\
\text { var mı? }\end{array}$ & 3 & 13,6 & 19 & 86,4 & 22 & 100 \\
\hline
\end{tabular}


Tablo IV'deki bulgular incelendiğinde üniversitelerin \%72,7'sinin basılı belgelere erişim ve yetkilendirmelerin tanımlandığı düzenlemelere sahip olmadıkları gözlenmektedir. Bu durum belirli konularda öneme haiz, gizliliği olan ya da sadece belirli konularda hizmete özel belgelerin tanımlanması, bu belgelere yönelik erişim haklarının belirlenmesini ve yetkilendirmelerin yapılmasını zorlaştırmaktadır. Diğer yandan Tablo IV'de sunulan bulgulara göre gizli ve önemli belgeler, araştırmada analiz edilen üniversitelerin yaklaşık yarısında $(\% 45,5)$ farklı alanlarda özel mekanizmalı raflarda korunmamaktadır. Bu doğrultuda ortaya çıkan durumun üniversitelerde belge yönetimi uygulamaları ve kurumsal iş süreçleri açısından ciddi güvenlik açıklarına neden olabileceği söylenebilir. Araştırmamızda, elektronik belge/arşiv kaynaklarının güvenliği ile ilgili bir diğer dikkat çekici bulgu ise üniversitelerde yapılan yazışmalarda elektronik imza kullanımı ile ilgilidir. Tablo IV'de de görüldüğü gibi resmi iş süreçlerinde yazışmalarda e-imza kullandığını belirten üniversitelerin oranı yalnızca \%9,1'dir. Benzer şekilde elektronik ortamda bilgi güvenliğine dönük ISO 27001 ve veya ISO 23081 standartlarını uyguladığını belirten üniversitelerin oranı da \%9,1'dir. Genellikle üniversitelerin bilgi işlem dairesi başkanlıklarına verilen bu sorumluluğa ilişkin bazı üniversiteler, konuya ilişkin geçiş süreçlerinin devam ettiğini ifade etmişlerdir. Belge ve arşiv kaynaklarına yönelik yapılanma ile ilgili bulgular incelendiğinde ise araştırmada yer alan üniversitelerin yalnızca \%13,6'sının dijital bir arşive sahip olduğu görülmektedir. Kurumsal yaşamın giderek daha yoğun biçimde elektronik ortamda yürütmeye başlandığı günümüzde dijital arşivler, sadece dijital ortamda üretilen belgeler için değil, basılı belgelerin dijital ortama aktarılmış formlarını da içermek durumundadırlar. Böylelikle iş süreçlerinde bilgi ve belge erişimi daha kolay ve hızı ıale gelebilecektir.

\section{Bilgi Teknolojilerine Yönelik Koşullar}

Araştırma kapsamında kullanılan veri toplama aracında üniversitelerde bilgi teknolojilerineyönelikaltyapı olanaklarıileilgiliuygulamaların ne şekildeyürütüldüğünü tanımlamaya dönük sorulara da yer verilmiştir. Bu sorular üniversitelerin genel sekreterlik makamlarından alınan izinler doğrultusunda, bilgi işlem dairesi başkanlarında konu uzmanı personel tarafından cevaplanmıştır. Bu doğrultuda öncelikle üniversitelerin bilgi teknolojileri bağlamında web ortamında yoğunlukla saldırıya maruz kaldıkları alanların neler olduğu belirlenmeye çalışılmıştır (Tablo V).

Tablo V. Üniversitelerin Web Ortamında Yoğunlukla Saldırıya Maruz Kaldığı Alanlar

\begin{tabular}{lcr}
\hline Sunucular & $\mathbf{n}$ & $\%$ \\
\hline E- posta sunucusu & 6 & 27,3 \\
Web sunucusu & 12 & 54,5 \\
FTP sunucusu & 2 & 9,1 \\
Diğer veri tabanı sunucuları & 3 & 13,6 \\
\hline
\end{tabular}


Üniversitelerin web ortamında yoğunlukla saldırıya maruz kaldığı alanları özetleyen Tablo V'e göre, araştırmada yer alan üniversitelerde en çok FTP sunucularının $(\% 45,5)$ ve web sunucularının $(\% 40,9)$ saldırıya uğradığı; e-posta ve diğer veri tabanı sunucularının ise daha az saldırıya uğradığı anlaşılmaktadır. Bu durumun oluşmasında sunucuların içerdiği bilginin niteliğinin etkili olduğu söylenebilir. Üniversitelerin web içeriklerini arşivlemek için kullandıkları ortamlar Tablo VI'da sunulmaktadır.

Tablo VI. Üniversitenin Web İçeriğinin Arşivlenme Yöntemi

\begin{tabular}{lrc}
\hline Arşivleme ortamları & $\mathbf{n}$ & $\%$ \\
\hline Merkezi sunucu & 7 & 31,8 \\
Farklı sunucular & 14 & 63,7 \\
Backup sunucu & 1 & 4,5 \\
\hline
\end{tabular}

Tablo Vl'da verilen bulgulara göre üniversitelerde web içerikleri çoğunlukla $(\% 63,7)$ farklı sunucularda arşivlenmektedir. Diğer yandan üniversitelerin \%31,8'i web içeriklerini merkezi sunucuda ve \%4,5'i ise yedekleme sunucusunda arşivlemektedir. Üniversitelerin yedekleme ünitesi olarak ağırlıklı biçimde farklı bir sunucuyu seçmesi, güvenlik açısından riskleri bir nebze azaltmaktadır. Bunun yanı sıra bulgularda, merkezi sunucuyu kullanan üniversitelerin bir bölümünün birden çok ortam kullandığı ve yedekleme için aynı zamanda farklı bir sunucudan da faydalandıkları görülmektedir. Üniversitelerin ürettikleri web içeriklerini arşivleme sıklıkları ise Tablo VII'de verilmektedir.

Tablo VII. Üniversitelerin Web İçeriğinin Arşivlenme Sıklığı

\begin{tabular}{lrc}
\hline Arşivleme sıklıkları & $\mathbf{n}$ & $\%$ \\
\hline Günlük & 14 & 63,7 \\
Haftalık & 4 & 18,2 \\
Aylık & 3 & 13,6 \\
2-6 Aylık & 1 & 4,5 \\
\hline
\end{tabular}

Tablo VII'de özetlenen ve üniversitelerde web içeriklerinin arşivlenme sıklığına yönelik bulgular değerlendirildiğinde, üniversitelerin \%63,6'sının web içeriklerini günlük olarak arşivledikleri görülmektedir. İnternet ortamında saldırıların sıklığı düşünüldüğünde, haftalık olarak arşivlediğini dile getiren \%18,2'lik kesim için belirli bir riskin var olduğu, 2-6 ay seçeneğini işaretleyen \%13,6'lık kesim için ise bu riskin ciddi boyutlarda olabileceği söylenebilir. Araştırmada üniversitelerin web içeriklerinin arşivlenme sıklıklarının ardından söz konusu içeriklerin e-posta sistemleri ile birlikte denetimine yönelik uygulamalarla ilgili bulgular da elde edilmiştir (Tablo VIII). 
Tablo VIII. Üniversitelerde e-posta ve Web İçeriğinin Denetimine Dönük Uygulamalar

\begin{tabular}{|c|c|c|c|c|c|c|}
\hline \multirow{2}{*}{ Uygulamalar } & \multicolumn{2}{|c|}{ Evet } & \multicolumn{2}{|c|}{ Hayır } & \multicolumn{2}{|c|}{ Toplam } \\
\hline & $\mathbf{n}$ & $\%$ & $\mathbf{n}$ & $\%$ & $\mathbf{n}$ & $\%$ \\
\hline $\begin{array}{l}\text { Web içeriğinin arşivlenmesi, güvenliği ile erişim ve } \\
\text { yetkilendirmeler üzerine yazılı politikaları var mı? }\end{array}$ & 12 & 57,1 & 9 & 42,9 & 21 & 100 \\
\hline $\begin{array}{l}\text { Üniversite uzantılı e-postalarının arşivlenmesi ve erişimine } \\
\text { yönelik düzenlemeler var mı? }\end{array}$ & 18 & 81,8 & 4 & 18,2 & 22 & 100 \\
\hline Web site bağlantıları denetleniyor mu? & 15 & 71,4 & 6 & 28,6 & 21 & 100 \\
\hline $\begin{array}{l}\text { Web site bağlantılarına erişimi sınırlamak için filtreleme yazılımı } \\
\text { kullanılıyor mu? }\end{array}$ & 15 & 68,2 & 7 & 31,8 & 22 & 100 \\
\hline Yasal ve idari nedenlerle kişisel e-posta içerikleri denetleniyor mu? & 3 & 13,6 & 19 & 86,4 & 22 & 100 \\
\hline
\end{tabular}

Tablo VIII'deki bulgulara göre araştırmada yer alan üniversitelerin \%42,9'u web içeriğinin arşivlenmesi, güvenliği, erişim ve yetkilendirmeler üzerine yazılı bir politikaya sahip değildir. İnternet'in önemli bir bilgi kaynağı olmasının yanında günlük yaşamın önemli bir kısmının yürütüldüğü bir platform oluşu, bilgi ve kültür mirasının korunmasını, devamlılığını ve erişimini gerekli kılmaktadır. Web içeriklerinin geçmişe ilişkin süreçlerin anlaşılmasında kanıt niteliği taşıması, çok yönlü araştırmalar için yeniden erişimin sağlanmasını son derece önemli hale getirmektedir. Bu çerçevede üniversitelerin yazılı politikalara sahip olması, bu kurumlar için büyük bir anlam taşımaktadır. Ayrıca üniversitelerin \%18,2'lik bir kısmının kurumsal e-postaların arşivlenmesi ve erişimine dönük düzenlemelere sahip olmaması da dikkat çekmektedir. Diğer taraftan araştırmada yer alan üniversitelerin yaklaşık dörtte üçlük bölümü $(\% 71,4)$ kendi sunucuları aracılığıyla erişilen web site bağlantılarını denetim altında tutmaktadır. Üniversitelerin üçte ikilik bölümünden fazlası $(\% 68,2)$ web site bağlantılarına erişimi sınırlamak için bir filtreleme yazılımı kullanırken, yasal ve idari nedenlerle kişisel e-posta içeriklerini denetleme yaptığını belirten üniversitelerin oranı \%13,6'da kalmaktadır. Üniversitelerde elektronik sistemlere yönelik olarak sıklıkla yaşanan sorunlar Tablo IX'da verilmektedir.

Tablo IX. Üniversitelerde Elektronik Sistemlerle İlgili Yoğunlukla Karşılaşılan Sorunlar

\begin{tabular}{lcccccc}
\hline \multirow{2}{*}{ Sorunlar } & \multicolumn{2}{c}{ Evet } & \multicolumn{2}{c}{ Hayır } & \multicolumn{2}{c}{ Toplam } \\
\cline { 2 - 7 } & $\mathbf{n}$ & $\%$ & $\mathbf{n}$ & $\%$ & $\mathbf{n}$ & $\%$ \\
\hline Elektronik içeriğin uzun süre korunması & 6 & 22,7 & 16 & 81,3 & 22 & 100 \\
Güvenlik tehditleri & 4 & 19,0 & 17 & 81,0 & 21 & 100 \\
Aranan bilgiye erişim sorunları & 13 & 61,9 & 8 & 38,1 & 21 & 100 \\
Bilgi bütünlüğünün ve özgünlüğünün korunamaması & 4 & 19,0 & 17 & 81,0 & 21 & 100 \\
Yedekleme olanaklarının yetersizliği & 3 & 14,3 & 18 & 85,7 & 21 & 100 \\
\hline
\end{tabular}


Tablo IX'a göre, üniversitelerde elektronik sistemlerle ilgili olarak sıklıkla karşılaşılan sorunun, bilgiye erişim $(\% 61,9)$ olduğu görülmektedir. Birden fazla seçeneğin işaretlenebildiği soruda diğer seçeneklere ait oranlar \%25'in altında kalmaktadır. Bu doğrultuda elektronik içeriğin uzun süre korunması \%22,7 oranıyla ikinci sırada yer alırken, bilgi bütünlüğü ve özgünlüğünün korunması ile güvenlik tehditleri \%19'luk oranla üçüncü sırada belirtilen sorunlar olmuştur. Diğer yandan yedekleme olanaklarının yetersizliği seçeneğinin işaretlenme oranı ise \%14'de kalmıştır. Bu bulgular, üniversitelerin alt yapı olanaklarından çok bilgiye erişim sistemlerinin geliştirilmesine ihtiyaç duyduklarını yansıtmaktadır. Araştırmada son olarak üniversitelerde elektronik ortamda yazışma ve belge sistemlerine dönük uygulamalarla ilgili bulgular elde edilmiştir (Tablo X).

Tablo X. Üniversitelerde Elektronik Ortamda

Yazışma ve Belge Sistemlerine Dönük Uygulamalar

\begin{tabular}{lcrrrrr}
\hline Uygulamalar & \multicolumn{2}{c}{ Evet } & \multicolumn{2}{c}{ Hayır } & \multicolumn{2}{c}{ Toplam } \\
\cline { 2 - 7 } & $\mathbf{n}$ & $\%$ & $\mathbf{n}$ & $\%$ & $\mathbf{n}$ & $\%$ \\
\hline $\begin{array}{l}\text { Elektronik ortamda yazışma ve diğer belgelerin kısa orta ve uzun } \\
\text { vadede saklama koşulları tanımlanmış mı? }\end{array}$ & 7 & 31,8 & 15 & 68,2 & 22 & 100 \\
$\begin{array}{l}\text { Elektronik belgelerin uzun süre korunmasına yönelik önlemler } \\
\text { alınmış mı? }\end{array}$ & 8 & 36,4 & 14 & 63,6 & 22 & 100 \\
$\begin{array}{l}\text { Elektronik belgelere erişme yönelik yetkilendirmeler } \\
\text { tanımlanmış mı? }\end{array}$ & 9 & 40,9 & 13 & 59,1 & 22 & 100 \\
$\begin{array}{l}\text { Üniversite içerisinde elektronik belgelerin özgünlüğünün } \\
\text { korunmasına yönelik (nitelikte e-imza gibi) alt yapı } \\
\text { oluşturulmuş mu? }\end{array}$ & 4 & 18,2 & 18 & 81,8 & 22 & 100 \\
\hline
\end{tabular}

Tablo X'a göre üniversitelerin \%68,2'sinde elektronik ortamda gerçekleştirilen yazışmalar ve diğer belgeler için kısa, orta ve uzun vadede saklama koşulları tanımlanmamıştır. Bu üniversitelerden bir kısmında ise yazışmaların elektronik ortamda yürütülmediği düşünülebilir. Oysakiyazışma ve diğer belgelerin elektronikortamdayaşam döngüsünün tanımlanmasına yönelik çalışmalara, sistemler uygulamaya geçmeden başlanmış olması önem taşımaktadır. Elektronik belgelerin uzun süre saklanması ve erişimine dönük uygulamaların gerçekleştirilmesi konusunda da benzer çalışmaların yapılması gerekmektedir. Bununla birlikte üniversitelerin büyük çoğunluğunda $(\% 81,8)$ elektronik belgelerin özgünlüğünün korunmasına yönelik olarak e-imza ve benzeri alt yapı olanaklarının geliştirilmesine ciddi anlamda gereksinim duyulduğu anlaşılmaktadır.

\section{Sonuç ve Öneriler}

Kurumsal iş süreçlerinin yönetiminde birçok amaca yönelik olarak geliştirilen bilgi sistemleri, kurumun kültürüne göre şekil alan ve kurum kimliğini yansıtan platformlardır. Bilgi sistemleri kapsam olarak kurumların faaliyet gösterdikleri alana ve sektöre göre 
çeşitlilik gösterse de gelişen teknoloji olanaklarının da etkisiyle web içerik yönetimi, belge yönetimi, doküman yönetimi ve e-posta sistemleri gibi bilgi sistemlerinin hemen hemen bütün kurumlarda yaygın olarak kullanıldığını söylemek mümkündür. Ayrıca söz konusu sistemlerin, teknolojik gelişmeler, kullanıc beklentilerindeki değişiklikler ve güvenlik uygulamaları çerçevesinde değerlendirilmesi ve güncellenmesi gerekmektedir. Bu kapsamda kurumsal bilgi sistemlerinin değerlendirilmesine yönelik araçlar geliştirilerek çok boyutlu analizler yapılmaktadır. Bilgi sistemlerini yoğunlukla kurumlardan biri de üniversitelerdir. Örgütsel yapıları gereği akademik ve idari birimler, araştırma merkezleri ve teknokentler gibi birimleri bünyesinde bulunduran üniversiteler sahip oldukları altyapı olanakları doğrultusunda bilgi sistemlerinden faydalanmakta; araştırma geliştirme faaliyetlerini takip ederek bu birimlerin işlevlerini en kolay ve hızlı biçimde sağlamaya yönelik ihtiyaçları karşılamaya çalışmaktadırlar. Bu doğrultuda çalışmada üniversitelerin sahip oldukları bilgi sistemlerinin ve bilgi sistemlerine yönelik uygulamalarının analiz edilmesi için bir analiz formu geliştirilerek Türkiye'de idari ve akademik personel sayısına göre sıralamada ilk 35'e giren kamu üniversitelerinden izinleri sağlanan 22 üniversitede uygulanmıştır. Analizler sonucunda genel olarak;

$\diamond \quad$ Üniversitelerin kurum içi ve dışı yazışmaları ile diğer resmi bilgi ve belge işlemlerine dönük işlemlerinin Genel Sekreterlik Makamı tarafından yürütüldüğü,

$\diamond \quad$ Üniversitelerde kurumsal iletişime, bilgi ve belge işlemlerine ve arşiv hizmetlerine yönelik olarak merkezi bir yapılanmanın bulunmadığı ve bu çalışmaların birimlerin inisiyatiflerine bırakıldığı,

$\diamond$ Arşiv hizmetlerine yönelik bir yönetmeliğe ve web içerikleriyle ilgili arşivleme, güvenlik, erişim ve yetkilendirmeler konusunda yazılı bir politikaya sahip olunmadığı,

$\diamond \quad$ Elektronik ortamda gerçekleştirilen yazışmalar ve diğer belgeler için kısa, orta ve uzun vadede saklama koşullarını tanımlayan saklama planlarının bulunmadığı,

$\diamond$ Belgelerin tasfiyesi için ayıklama ve imha komisyonlarının oluşturulduğu, bu komisyonların uygulamalarını saklama planları olmadan gerçekleştirdiği,

$\diamond \quad$ Elektronik belge yönetim sistemlerinin kullanılmadığı,

$\diamond$ Donanımsal olarak e-imzaya sahip olmalarına rağmen e-imza kullanımının düşük olduğu,

$\diamond$ Bilgi güvenliği standartlarının tam anlamıyla uygulanmadığı,

$\diamond \quad$ Web içeriklerinin farklı sunucularda günlük olarak arşivlendiği ve bu içeriklere yönelik saldırılara maruz kalındığı,

$\diamond \quad$ Analiz sorularına yanıt veren üniversitelerdeki bilgi işlem uzmanlarının görüşleri doğrultusunda; içeriğin uzun süre korunması, bilgi bütünlüğü ve özgünlüğünün korunması konularında güvenlik tehditlerinin bulunduğu,

$\diamond$ Elektronik sistemlerle ilgili olarak bilgiye erişimde sorunla karşılaşıldığı, 
$\diamond$ Bilgi erişim sistemlerinin ve elektronik belgelerin özgünlüğünün korunmasına yönelik olarak e-imza ve benzeri alt yapı olanaklarının geliştirilmesine ciddi anlamda gereksinim duyulduğu anlaşılmıştır.

Yukarıdaki sonuçlar içerisinde yer alan, üniversitelerin donanımsal olarak e-imzaya sahip olmalarına rağmen, e-imza kullanımının düşük olması üzerinde ayrıca durulması gerekmektedir. İlerleyen dönemlerde konu üzerine farklı çalışmaların yapılması önemli görülmektedir.

Çalışmamız kapsamında, üniversitelerin kurumsal iletişime, bilgi ve belge işlemlerine ve arşiv hizmetlerine yönelik olarak mevcut uygulamalarını gözden geçirmeleri, kurumsal bir politika geliştirmeleri ve ulusal/uluslararası standartlara dayanarak standart dosya planları oluşturmaları oldukça önemli görülmektedir. Ayrıca, üniversitelerde bilgi ve belge işlemleri ile arşiv hizmetlerinin yürütülmesi için Bilgi ve Belge Yönetimi Daire Başkanlığı şeklinde merkezi bir yapının oluşturulması, üniversitenin tüm birimleri arasında ilgili çalışmaların kolaylıkla gerçekleştirilmesi ve koordinasyonun sağlanması açısından büyük yararlar sağlayacaktır.

\section{Açıklama}

Bu çalışma ve çalışmada sunulan veriler, Türkiye Bilimsel ve Teknolojik Araştırma Kurumu (TÜBITAK) tarafından UBAP 1011 Uluslararası Araştırma Projeleri çerçevesinde desteklenen 109K518 numaralı Elektronik Sistemlerde Belgelerin Özgünlüğünün Korunması başlıklı projeye dayanmaktadır.

\section{Kaynakça}

Ayıklama ve Imha Işlemlerinde DAGM'nün Uygun Görüşünün Alınması, Yıllık Arşiv Faaliyet Raporunun Aksatılmadan Gönderilmesi, Yönetim Kurulu ve Benzeri Kararlar Ile Eski Harfli Türkçe Arşiv Malzemesinin Bekletilmeden Devlet Arşivlerine Devri. Başbakanlık Genelgesi, Sayı: 18975, 20 Ekim 1998.

Ayıklama ve imha komisyonlarına ait çalışma rehberi ve Devlet Arşivlerine Arşivlerine devir işlemleri: 3473 sayılı Muhafazasına Lüzum Kalmayan Evrak ve Malzemenin Yok Edilmesi Hakkında Kanun kapsamında yer alan kurum ve kuruluşlarda. (1996). S. Saraç ve M. Torunlar (Yay. Haz.). Ankara: DAGM.

Barutçugil, ì. (2002). Bilgi yönetimi. İstanbul: Kariyer Yayıncılık.

Baş, T. (2001). Anket: anket nasıl hazırlanır, anket nasıl uygulanır, anket nasıl değerlendirilir. Ankara: Seçkin.

Bilgi Edinme Hakkı Kanunu. (2003). Resmî Gazete, Sayı: 25269, 24 Ekim 2003.

Bingi, P., Golda, J. K. ve Sharda, M. K. (1999). Critical issues affecting an ERP implementation. Information Systems Management, 16(3), 7-15.

Cain, P. (2002). Model requirement for the management of electronic records (MoReq): A critical evaluation. Records Management Journal, 12(1), 14-18. 
Cimtech Ltd. (2009). Managing information and documents: the definitive guide. Birleşik Krallık: Cimtech Innovation Centre

Cisco, S. L. ve Strong, Karen V. (1999). The value added information chain. Information Management Journal, 33(1).

Çakmak, T. (2011). Kurumsal içerik yönetimi kapsamında elektronik bilgi ve belge sistemlerinin bir kurum örneğinde değerlendirilmesi. Yayınlanmamış yüksek lisans tezi. Ankara: Hacettepe Üniversitesi

Çeven, M. (2006). Kurumsal bilgi sistemlerinin karar vermeyi destekleyici özellikleri ve bir uygulama. Yayınlanmamış yüksek lisans tezi, Gaziantep Üniversitesi, Gaziantep.

Çiçek, N. (2000). ISO 9000 Kalite güvence sistemi standardında evrak üretimi ve yönetimi. Arşiv Araştırmaları Dergisi, 2, 7-34.

Demir, S. (2000). Kurumsal kaynak planlaması. Bilgi Teknolojileri Haber Bülteni, 12, 14-18.

Demp, S. (2004). An introduction to Records Management Capacity Assessment System (RMCAS). Esarbicas Newsletter, October 2004, 8-13.

Devlet Arşiv Hizmetleri Hakkında Yönetmelik. (1988). Resmî Gazete, Sayı: 19816, 16 Mayıs 1988.

Devlet Arşiv Hizmetleri Hakkında Yönetmelikte Değişiklik Yapılmasına Dair Yönetmelik.(2001). T.C. Resmi Gazete, Sayı: 24487, 8 Ağustos 2001, 95-100. Devlet Arşivleri Genel Müdürlüğü Cumhuriyet Arşivleri Daire Başkanlığı,

Devlet Arşiv Hizmetleri Hakkında Yönetmelikte Değişiklik Yapılmasına Dair Yönetmelik. (2005). Resmi Gazete, Sayı: 25735, 22 Şubat 2005.

Dollar, C. M. (2002). Authentic electronic records: Strategies for long term access. Chicago: Cohasset Association.

Duff, W. ve McKemmish, S. (2000). Metadata and ISO compliance. Information Management Journal, 34(1), 1-8.

Elektronik İmza Kanunu. (2004). Resmî Gazete, Sayı: 25355, 23 Ocak 2004.

Griffin, A. (2004). Records management capacity assessment system (RMCAS). Archival Science, 4, 71-97.

Hare, C. E. ve McLeod, J. (1997). Developing a record management programme. London: Aslib.

Information management planning. (2005). Government of Alberta Information Management Branch. 3 Eylül 2007 tarihinde http://www.im.gov.ab.ca/publications/pdf/IMPlanningGuide. pdf adresinden erişildi.

İcimsoy, A. O. (1997). Arşivlerde mikroform kullanımı: Yeni teknolojiler ve sorunlar. Bilgi Çağı, Bilgi Merkezleri ve Bilgi Teknolojileri Sempozyumu 7-9 Mayıs 1997 - Bildiriler içinde (ss.7-14). Ankara: Ankara Üniversitesi, 1999.

Kandur, H. (2011). Türkiye'de kamu kurumlarında elektronik belge yönetimi: mevcut durum analizi ve farkındalığın artııı ması çalışmaları. Bilgi Dünyası, 12(1), 2-12

Kandur, H. (1998). Arşivlerde kullanıc hizmetleri ve bilgisayar kullanımı. I. Milli Arşiv Şurası (Tebliğler-Tartışmalar) <20-21 Nisan 1998 Ankara> içinde (s.579-588). Ankara: Başbakanlık Devlet Arşivleri Genel Müdürlüğü. 
Karasar, N. (1991). Bilimsel araştırma yöntemi: kavramlar, ilkeler teknikler (4.bs.). Ankara: Sancak Matbaası

Karasar, N. (2004). Bilimsel araştırma yöntemi. Ankara: Nobel.

Kumar, N. ve Mittal, R. (2004). Management information system. New Delhi: Anmol.

Külcü, Ö. (2005). Kamu üniversitelerinde kalite yönetimi ve kalite sistem dokümantasyonu çerçevesinde belge yönetimi. Yayımlanmamış doktora tezi, Hacettepe Üniversitesi, Ankara.

Külcü, Ö. (2006). Küreselleşme Sürecince Avrupa Birliği'nde Belge Yönetimi Uygulamaları ve Türkiye. Bilgi Dünyası 7(2), 202-229.

Külcü, Ö. ve Uzun Külcü, H. (2009). Belge yönetiminde program geliştirme: Belge Yönetimi Kapasite Değerlendirme Sistemi. Bilgi Dünyası, 10 (2), 261-285.

Laudon, K. C. ve Laudon, J. P. (2000). Management information systems: organization and technology in the networked enterprise (6. bs.). New Jersey: Prentice-Hall, Inc.

Mabert, A. M., Soni, A. ve Venkataraman, M. A. (2001). Enterprise resource planning: common myths versus evolving reality. Business Horizons, 44(3), 69-76.

Muhafazasına Lüzum Kalmayan Evrak ve Malzemenin Yok Edilmesi Hakkında Kanun. (1988). Resmî Gazete, Sayı: 19949, 04 Ekim 1988.

Odabaş, H. (2003). Kurumsal bilgi yönetimi. Türk Kütüphaneciliği, 17(4), 357-368.

Odabaş, H. (2007). Elektronik belge yönetimi ve kamu kurum ve kuruluşları. Yayımlanmamış doktora tezi, Ankara: Ankara Üniversitesi.

Özdemirci, F. (1996). Kurum ve kuruluşlarda belge üretiminin denetimi ve belge yönetimi. İstanbul: Türk Kütüphaneciler Derneği İstanbul Şubesi Yayınları.

Özdemirci, F. (2004). Bir disiplin olarak belge yönetimi. Kütüphaneciliğin Destanı Uluslararası Sempozyumu 21-24 Ekim 2004, Ankara, bildiriler içinde (s. 191-210). Ankara: Ankara Üniversitesi Bilgi ve Belge Yönetimi.

Özdemirci, F. (2012). Kurum Arşivlerinden Milli Arşive Kurumsallaşma Süreci ve Elektronik Belge Yönetiminden E-Devlete. Arşiv Dünyası, 13, 38-44.

Özdemirci, F. ve Aydın, C. (2007). Kurumsal bilgi kaynakları ve bilgi yönetimi. Türk Kütüphaneciliği, 21(2), 164-185.

Özdemirci, F., Torunlar, M ve Saraç, S. (2009). Üniversiteler için belge yönetimi ve arşiv sistemi-işlemleri (BEYAS) el kitabı. Ankara: BEYAS

Parr, A. ve Shanks, G. (2000). A Taxonomy of ERP implementation approaches. Proceedings, 33rd Hawaii International Conference on System Sciences içinde. Hawaii: University of Hawaii. 13 Kasım 2010 tarihinde http://citeseerx.ist.psu.edu/viewdoc/download?doi=10.1.1.98.3458\&re $p=r e p 1 \&$ type $=p d f$ adresinden erişildi.

Pember, M. (2006). Sorting out the standards: what every records and information professional should know. Records Management Journal, 16(1), 21-31.

Penn, I. A., Mordel, A. ve Pennix, G. (1994). Record management handbook. Kelvin Smith: Gower.

Resmi Yazışmalarda Uygulanacak Esas ve Usuller Hakkında Yönetmelik. (2004). Resmi Gazete, Sayı: 25658, 2 Aralık 2004, 5-26. 
Shepherd, E. ve Geoffrey Y. (2003). Managing records a handbook of principles and practices. London: Facet Publishing.

Smith, R. J. ve Kallaus N. F. (1997). Records management. Cincinnati, OH: South Western Education Publishing.

Spiegler, I. (2002). Technology and knowledge: bridging a 'generating' gap. Information and Management, 2013, 1-7.

Spratt, R. (2004). Records management: the next ten years. RDIMS (Records, Documents and Image Management Systems). Canadian Federal Government Shared System Initiative. 8 Haziran 2006 tarihinde https://www.rdims.com/Documents/ WhitePaper-RecordsManagement-The NextTenYears.doc adresinden erişildi.

Standart Dosya Planı. (2005). Başbakanlık Personel ve Prensipler Genel Müdürlüğü Genelge, Sayı: 320-3802, 24 Mart 2005.

Şahin, M. (2005). Yönetim bilgi sistemleri (3. bs.). Eskişehir: Anadolu Üniversitesi.

Thurston, A. (2005). Fostering trust and transparency through information systems. ACARM Newsletter, 36, 1-5.

TS 13298. (2009). Elektronik belge yönetimi. Ankara: Türk Standartları Enstitüsü.

TS ISO 15489-1. (2007). Bilgi ve dokümantasyon - Belge yönetimi Bölüm 1: Genel. Türk Standartlar Örgütü: Ankara.

TSE ISO/TR 15489-2. (2007). Bilgi ve dokümantasyon - Belge yönetimi - Bölüm 2: Kılavuzlar. Türk Standartlar Örgütü: Ankara.

Williams, R. F. (2002). Realizing the need and putting the key components in place to getting it right in records management. Maryland: AllM International.

Zawiyah, M. Y. ve Chell, R. W. (2002). Towards a theoretical construct for records management. Records Management Journal, 12(2), 55-64. 